\title{
MARINE ENVIRONMENT QUALITY ASSESSMENT OF THE SKAGERRAK - KATTEGAT
}

\author{
RUTGER ROSENBERG ${ }^{1}$, INGEMAR CATO ${ }^{2}$, LARS FÖRLIN ${ }^{3}$, KJELL GRIP $^{4}$ and JOHAN RODHE ${ }^{5}$ \\ ${ }^{1}$ Göteborg University, Kristineberg Marine Research Station, S-450 34 Fiskebäckskil, Sweden \\ ${ }^{2}$ Geological Survey of Sweden, Box 670, S-751 28 Uppsala, Sweden \\ ${ }^{3}$ Göteborg University, Department of Zoophysiology, Medicinaregatan 18, S-413 90 Göteborg, Sweden \\ ${ }^{4}$ Swedish Environment Protection Agency, S-106 48 Stockholm, Sweden \\ ${ }^{5}$ Göteborg University, Department of Oceanography, Earth Science Centre, S-413 81 Göteborg, Sweden
}

\begin{abstract}
This quality assessment of the Skagerrak-Kattegat is mainly based on recent results obtained within the framework of the Swedish multidisciplinary research projekt 'Large-scale environmental effects and ecological processes in the Skagerrak-Kattegat' completed with relevant data from other research publications. The results show that the North Sea has a significant impact on the marine ecosystem in the Skagerrak and the northern Kattegat. Among environmental changes recently documented for some of these areas are: increased nutrient concentrations, increased occurrence of fast-growing filamentous algae in coastal areas affecting nursery and feeding conditions for fish, declining bottom water oxygen concentrations with negative effects on benthic fauna, and sediment toxicity to invertebrates also causing physiological responses in fish. It is concluded that, due to eutrophication and toxic substances, large-scale environmental changes and effects occur in the Skagerrak-Kattegat area.
\end{abstract}

Key words: eutrophication, contaminants, nutrients, oxygen concentrations, toxicity, benthos, fish

\section{INTRODUCTION}

The Kattegat and the Skagerrak (Fig. 1), with surface areas of about 22000 and $32000 \mathrm{~km}^{2}$ and mean depths of 23 and $210 \mathrm{~m}$, respectively, connect the brackish Baltic Sea with the North Sea, where the salinity is almost oceanic (Svansson, 1975). Water of Baltic origin forms a surface layer in the Kattegat with a salinity increasing from 15 psu in the southeast to 25 psu in the northwest. Water originating from the North Sea is found below a pronounced halocline at a depth of about $15 \mathrm{~m}$. The salinity in the deep water ranges from 32 to $34 \mathrm{psu}$. The Kattegat surface water is bounded to the north by a sharp surface front, on average directed from Skagen towards the northeast. From here on the low-saline water of Baltic origin follows the Swedish and Norwegian coasts in the Skagerrak as a low-saline coastal current.

The hydrographic conditions in the Skagerrak are dominated by a deep-reaching flow of water from the central and northern North Sea with a salinity close to $35 \mathrm{psu}$. The core of this flow follows the slopes of the Norwegian Trench around the Skagerrak in a cyclonic direction. This water constitutes the bulk of the water in the Skagerrak. A weaker inflow from the southern North Sea occurs close to the Danish coast, which is influenced by river discharge to the North Sea and has a salinity in the range of 31 to 34 psu. The entire surface of the Skagerrak is to some extent influenced by low-saline water from the costal current along the Swedish and Norwegian coasts, due to frequently occurring upwelling events (North Sea Task Force, 1993; Rodhe, 1996).

In some areas, with strong stratification and low water renewal, as in the southern parts of the Kattegat and in some fjords along the Swedish and the Norwegian coasts in the Skagerrak, seasonal oxygen deficiency may develop in combination with eutrophication (Aure \& Danielssen, 1995; Baden et al., 1990; Magnusson \& Johnsen, 1994; Rosenberg, 1990). The oxygen concentration in the deeper parts of the Skagerrak is stable, 5.5 to $7.3 \mathrm{~cm}^{3} \cdot \mathrm{dm}^{-3}$ (Aure \& Dahl, 1994; Dahl \& Danielssen, 1992).

A few studies have dealt with ecological aspects of the pelagic system in the open Skagerrak. Pingree et al. (1982), Kiørboe et al. (1990) and Bjørnsen et al. 


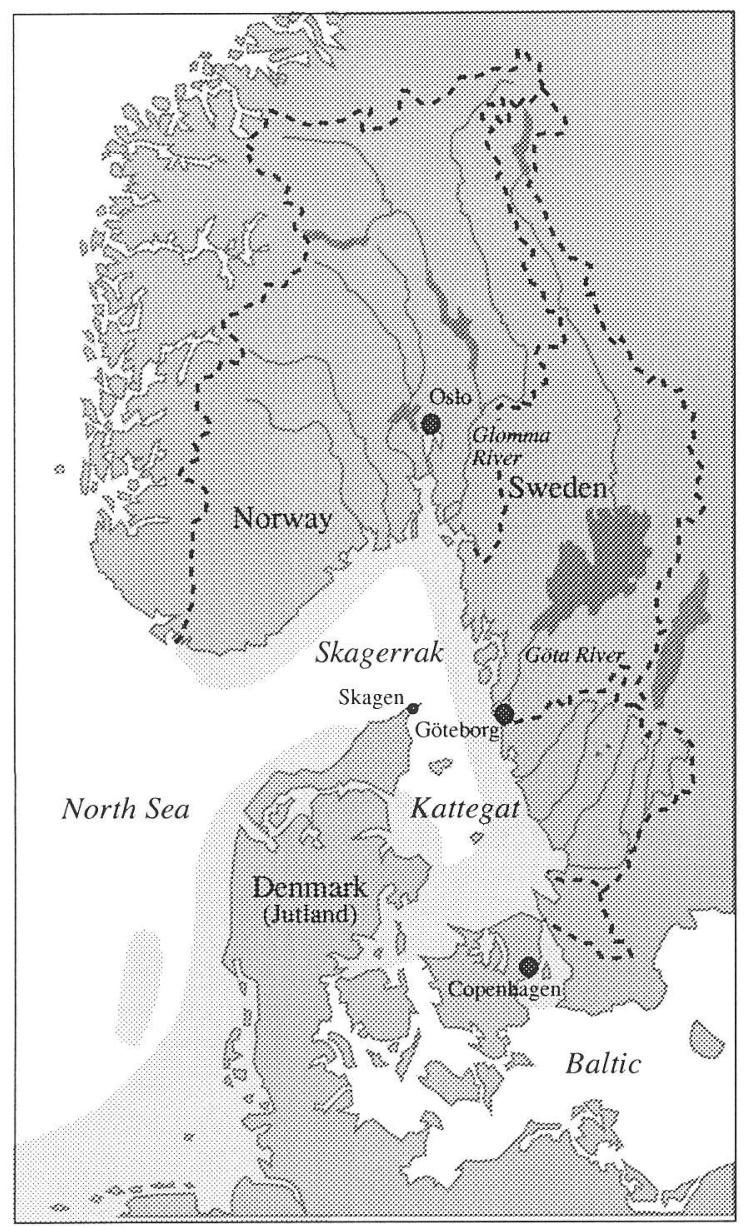

Fig. 1. Drainage areas (border lines indicated by ---) and main rivers discharging into the Skagerrak-Kattegat. Lightly shaded sea areas have been identified as eutrophicated problem areas by the Oslo and Paris Commissions (1992).

(1993) have found that, e.g. the doming of the pycnocline in the central eastern Skagerrak makes nutrients available to phytoplankton, and also that subsurface chlorophyll maxima frequently occur in the Skagerrak (see also Karlsson et al., 1996). Dense phytoplankton concentrations have also been observed in frontal zone waters at the Skagerrak-Kattegat border (Richardson, 1985). Another study in the open Skagerrak showed that most of the nitrogen used by phytoplankton in May was regenerated nitrogen, and that most of the carbon was channelled through the pelagic microbial system (Rosenberg et al., 1990a). Several experimental studies have shown that nitrogen stimulates algal growth in natural seawater, which suggests that nitrogen is generally the limiting nutrient for primary production (Granéli et al.,
1990). Exceptions to this can be local coastal areas with significant nitrogen run-off, or the later phase of the spring bloom when silica deficiency hampers growth of diatoms.

The sediment structure of shallow areas of the Kattegat and the northwestern Skagerrak off Jutland is rather coarse, predominantly sand and coarse silt. Deeper $(>75 \mathrm{~m})$ parts of the Skagerrak and the Deep Trench $(\approx 100 \mathrm{~m})$ intersecting the Kattegat from the north to the south are dominated by postglacial clayey sediments with an organic content of about $2 \%$ dry matter (Cato et al., 1992; Kuijpers et al., 1992). These areas are the main accumulation areas dominated by suspension deposition (Stevens et al., 1996), not only of the Skagerrak and the Kattegat, but also of the North Sea as a whole (Eisma \& Kalf, 1987; Van Weering \& Qvale, 1983). Other important sedimentation areas are found along the Norwegian and Swedish coasts of the Skagerrak, with their rugged coastline, rich in islands, skerries and fjords, and consequently sheltered bottom areas dominated by organic postglacial clays and fine silt. The highest sedimentation rate in the Skagerrak is found in the northeastern part, $>4 \mathrm{~mm} \cdot \mathrm{y}^{-1}$, with means of $\approx 2$ $\mathrm{mm} \cdot \mathrm{y}^{-1}$ at the slopes of the Norwegian Trench (van Weering et al., 1987).

In early 1990, the Swedish Environment Protection Agency launched the research project 'Large-Scale Environmental Effects and Ecological Processes in the Skagerrak-Kattegat' (Rosenberg et al., 1991) with the objectives to intensify marine research in the Skagerrak and the northern Kattegat, and to increase the knowledge on the environmental effects in these sea areas. It was suggested to put research emphasis on the influence of the North Sea on the open Skagerrak and the northern Kattegat and to investigate, for example, whether the accumulation bottoms in these areas are the dustbins for the North Sea. About 40 scientists and doctoral students have taken part in this multi-disciplinary project during 1990 to 1995, and a substantial part of the results are presented in this issue of the Journal of Sea Research (vol. 35, no.(1-3), 1996).

Preceding this project, the southern Kattegat was studied by Swedish scientists in a similar research project, the 'Eutrophication Project'. That project showed that strong seasonal environmental effects occur in that area due to eutrophication. Since the mid-1970s, excessive growth of filamentous algae occurs in spring and summer, and since 1980 bottom-water hypoxia occurs annually in late summer through autumn. The hypoxia is reducing benthic fauna and commercial catches of Norway lobster (Nephrops norvegicus) and demersal fish (Baden et al., 1990; Josefson \& Jensen, 1992a; Rosenberg et al., 1992). The suggested goals and measures to be taken to improve the environmental conditions in the southern Kattegat is discussed in Rosenberg et al. (1990b) and Fleischer et al. (1994). 


\section{INPUT OF NUTRIENTS AND CONTAMINANTS TO THE SKAGERRAK - KATTEGAT}

Input data of nitrogen and phosphorus from land and atmosphere are given in Table 1. Larger rivers and their drainage areas discharging into the Skagerrak-Kattegat are shown in Fig. 1. Approximately equal amounts of nitrogen enter the Kattegat from Denmark, Sweden and from the atmosphere. However, the largest Swedish contributor, the Göta River at Göteborg with a discharge of $\approx 17 \cdot 10^{6} \mathrm{~kg} \mathrm{~N} \cdot \mathrm{y}^{-1}$ is at the border of the Skagerrak. The largest riverine input to the Skagerrak comes from Norway and mainly from Glomma River.

The North Sea Task Force (1993) has estimated the transport of anthropogenic nitrogen and phosphorus from the Baltic to the Kattegat surface water at $13 \cdot 10^{7}$ and $1.1 \cdot 10^{7} \mathrm{~kg} \cdot \mathrm{y}^{-1}$, respectively, and from the southern North Sea to the Skagerrak at $40 \cdot 10^{7}$ and $3.5 \cdot 10^{7} \mathrm{~kg} \cdot \mathrm{y}^{-1}$. Recent measurements over the years 1990 to 1994 suggest that currents from the southern North Sea will transport $35 \cdot 10^{7} \mathrm{~kg} \cdot \mathrm{y}^{-1}$ of inorganic nitrogen and $60 \cdot 10^{7} \mathrm{~kg} \cdot \mathrm{y}^{-1}$ of total nitrogen into the Skagerrak (Rydberg et al., 1996). The annual variation is great. Eventually, some of this nitrogen will be transported to the Kattegat. In the southeastern Kattegat surface water the largest contribution of nitrogen comes from the Swedish rivers (Fleischer \& Jonsson, 1992).

According to the North Sea Task Force (1993) the input of heavy metals to the Skagerrak and the Kattegat is generally low. However, elevated concentrations, often up to ten times the background and occasionally up to 50 times, have been found for several elements $(\mathrm{Hg}, \mathrm{Cd}, \mathrm{Pb}, \mathrm{Cu}, \mathrm{Mo})$ in some fjords (Cato, 1977, 1983, 1990, 1992) and urbanized estuaries, particularly the Göta River estuary (Olausson, 1975; Cato, 1986, 1992; Kuijpers et al., 1993). Detailed studies have shown a close relationship between heavy metals and organic matter of the sediments (e.g. Cato, 1977). The results indicate that most metals discharged by river runoff are trapped in sediments within the coastal zone. Off the coast elevated concentrations of mercury have been found in the northeastern part of the Skagerrak (Cato, pers. comm.; O. Longva, pers. comm.), where the sedimentation rate was found to be high.

According to Kuijpers et al. (1993) lead and Chernobyl ${ }^{137} \mathrm{Cs}$ seem to be transported along the north Jutland coast to the Skagerrak. A considerable contribution of ${ }^{137} \mathrm{Cs}$ is also entering the region with the river run-off from Sweden and with the Baltic current along the Swedish coast.

Input data of organic contaminants to the Skagerrak-Kattegat are scarce, and it is known that most of these substances are generally transported in the atmosphere over long distances (Preston, 1992), which has also been shown for the Skagerrak-Kattegat (Brorström-Lundén, 1996). The highest concen-
TABLE 1

Annual input $\left(10^{3} \mathrm{~kg}\right.$ per year) of nitrogen and phosphorus to the Kattegat and Skagerrak from land run-off (1990) and via atmospheric dry deposition (1986-1990) (Lindahl et al., 1993).

\begin{tabular}{lrrrr}
\hline & Total-N & $\%$ & Total-P & $\%$ \\
\hline Kattegat & & & & \\
Sweden & 33900 & 35 & 1310 & 44 \\
Denmark & 35300 & 36 & 1570 & 52 \\
Atmosphere & 29000 & 30 & 130 & 4 \\
Total & 98200 & & 3010 & \\
Skagerrak & & & & \\
\hline Sweden & 3800 & 5 & 150 & 8 \\
Denmark & 3300 & 5 & 300 & 17 \\
Norway & 33900 & 46 & 1160 & 64 \\
Atmosphere & 32000 & 44 & 190 & 11 \\
Total & 73000 & & 1800 & \\
\hline
\end{tabular}

trations of polyaromatic hydrocarbons (PAHs), polychlorinated biphenyls (PCBs), hexachlorbenzene (HCB), pesticides such as lindane $(\mathrm{HCH})$, sum DDT and chlordane have been found in the sediments of the Göta River estuary, off Falkenberg, and for HCB off Stenungsund at the Swedish west coast (Cato, 1992). The surface sediments were up to $>100$ times more contaminated than the reference sediments off the Faroe Islands. According to Cato (1992) this indicates a strong input of contaminants by rivers and industrial discharges from the urbanized areas to the Skagerrak-Kattegat. The amount of PCB introduced by e.g. Göta River has been estimated at 10 to 15 $\mathrm{kg} \cdot \mathrm{y}^{-1}$ (Ahnoff \& Josefsson, 1975). However, as in the case of the heavy metals the organic micropollutants also seem to be trapped in the sediments rich in organic matter within the coastal zone. In Norwegian coastal waters elevated concentrations of e.g. $\mathrm{Hg}$, $\mathrm{PCB}, \mathrm{PAH}$ and dioxins were found in a gradient from the inner Friefjord (west of the Oslofjord) and out from the coast (Næs \& Oug, 1991). In the open Skagerrak-Kattegat the highest concentrations of DDT were found together with somewhat elevated concentrations of PAHs and PCBs. This is partly in accordance with Lohse (1988), who found that in general several organic pollutants were higher in the Skagerrak than in the North Sea sediments.

\section{ECOLOGICAL EFFECTS IN THE SKAGERRAK AND THE NORTHERN KATTEGAT}

\subsection{COASTAL AREAS}

Studies of pollution-induced ecological effects were initiated in the 1960s in the inner part of the Gullmarsfjord in Sweden. There, the benthic fauna was killed and reduced along a gradient from a river discharging effluent from a pulp mill (Leppäkoski, 1968). Later, benthic fauna in Swedish fjordic areas has undergone large-scale reductions due to eutrophication-induced 
hypoxia (Josefson \& Rosenberg, 1988; Josefson \& Widbom, 1988). These reductions are associated with low and significantly declining oxygen concentrations recorded in the bottom water at many fjord sites over the period from the 1950s to 1984 (Rosenberg, 1990).

In the same region the macroalgal vegetation has changed drastically over the last 10 years. Many shallow bays (30-40\%) are now covered by fast-growing filamentous green algae in spring to summer. This reduces important nursery and feeding grounds for coastal fish populations. Epiphytes on eelgrass (Zostera marina) have also been shown to reduce the number of fish species associated to these beds (Pihl et al., 1996; Pihl et al., 1995).

Disturbances in the Skagerrak coastal pelagic system have been reported by Lindahl \& Hernroth (1983). Occurrences of toxic algae with harmful biological effects seem to have increased over the last decades (Granéli, 1987). Some of these toxic algae have lately poisoned mussels (Mytilus edulis) for extended periods and affected their marketing (Haamer et al., 1990). Others, like Gyrodinium aureolum, have caused fish mortality (Dahl \& Tangen, 1993).

In 1977 to 1981 hypoxia caused mortality and behavioural changes of the benthic fauna in the enclosed Limfjord in Denmark (Jörgensen, 1980). Also in the Oslofjord in Norway (Mirza \& Gray, 1981) and in the Frierfjord (Gray et al., 1988) the benthic fauna has undergone negative changes due to enrichment and pollution over the last decades. Since around 1960-1970, oxygen concentration has declined at Drøbak in the Oslofjord (Magnusson \& Johnsen, 1994). In 1988/89 it was found that the macroalgal vertical distribution was reduced compared to 40 years earlier in the central and outer Oslofjord (Rueness \& Fredriksen, 1991). In another study it was shown that several species of Fucus had increased their abundance from the period 1974-1980 to 1988-1990 in the inner Oslofjord. This was suggested to relate to improvements in sewage treatment and discharge practices (Bokn et al., 1992).

\subsection{OPEN SEA AREAS}

In May 1988, the extremely toxic flagellate Chrysochromulina polylepis spread rapidly in the surface water almost all over the Skagerrak-Kattegat and killed and reduced both pelagic and benthic fauna down to 15 to 20 m (Lindahl \& Dahl, 1990; Lindahl \& Rosenberg, 1989; Rosenberg et al., 1988). In one Norwegian coastal area, benthic fauna down to 180 $m$ depth seems to have been affected by these sedimenting algae (Olsgard, 1993).

In offshore areas, temporal trends in macrobenthic fauna have been assessed in a number of investigations. In the 1980s, 25 stations were sampled in the Kattegat (Pearson et al., 1985) and 23 in the eastern
Skagerrak including the mouth of the Oslofjord (Rosenberg et al., 1987). The same sites were investigated already at the beginning of this century. The overall results suggest that the benthic fauna in the well-ventilated bottom areas of the northern Kattegat and the open Skagerrak had gained in biomass in the 1980 s, but that the fauna in the stratified southern Kattegat had been reduced in biomass during the same period. Similar temporal trends were found during the 1970-1980s with declining biomasses in the southern Kattegat (Josefson \& Jensen, 1992a; Rosenberg et al., 1992) and increasing biomass in the northern Kattegat and the eastern Skagerrak (Josefson, 1990; Josefson \& Jensen, 1992b). All these authors strongly suggest that the increased eutrophication over the last decades has caused a large-scale enrichment of the bottoms in the open Kattegat and the open eastern Skagerrak. In stagnant areas, however, the result has been seasonally (summer-autumn) occurring hypoxic bottom water.

In the Norwegian Trench, both the benthic meioand macrofauna seem to be structured by sediment characteristics, transport and accumulation (Bergsten et al., 1996; Boveé et al., 1996; Rosenberg et al., 1996). There is no obvious indication of a disturbance of these benthic communities due to pollution or hypoxia.

The sediment in the Norwegian Trench is, however, contaminated by organic pollutants such as DDT, $\mathrm{PAH}$ and PCB. Mussels (Mytilus edulis) caged in the area accumulated PAHs and had higher detoxification enzyme activities than mussels caged in pristine areas outside the Faroe Islands. The roundnose grenadier (Coryphaenoides rupestris) had enhanced levels of detoxification enzymes and showed histopathological changes compared with fish populations of the same species from the Faroe Islands (Förlin et al., 1996). Overall, these biomarker responses in Roundnose grenadier and caged mussels indicate impact of PAH (Förlin et al., 1995). Experimental studies of sediments from the Norwegian Trench, the eastern Skagerrak and the northern Kattegat have shown toxic effects on the crustaceans Nitocra spinipes and Daphnia magna (whole sediment), on mussel (Mytilus edulis) larvae (pore water), on rainbow trout (Oncorhynchus mykiss) (solvent extracts), and on the denitrification rate (Dave \& Nilsson, 1994; Magnusson et al., 1996). Sites at the Göta River estuary, eastern Skagerrak and the Norwegian Trench were considered most polluted. This is the first time ecological and physiological effects due to sediment toxicity have been reported from the open Skagerrak.

In 1980s the body burden of SDDT and PCB in juvenile harbour seals (Phoca vitulina) was about $1 / 4$ to $1 / 2$ in the Kattegat-Skagerrak compared with in the Baltic. Concentrations did not differ significantly between seals found dead during the mass mortality in 1988, caused by the virus epizootic, and animals 
collected in unaffected areas (Blomkvist et al., 1992). There is a possibility that the seals were suffering from immuno-suppression due to pollution prior to the virus outbreak, but such a relationship has not been established.

Regarding commercial fish species, no clear environmental effects have been established in the northern Kattegat and the Skagerrak, except from the effects of the fisheries themselves. However, in the seasonally hypoxic southern Kattegat a clear decline was shown in the catches of cod (Gadus morhua) and Norway lobster (Nephrops norvegicus) in the 1980s. During late summer-autumn the demersal fish species disappear from the hypoxic bottoms, which in some years encompassed 2000 to $4000 \mathrm{~km}^{2}$ (Baden et al., 1990). During hypoxic periods the demersal fish catches have been reduced by 75 to $95 \%$ of the biomass. From 1980 onwards the landings of plaice (Pleuronectes platessa) have declined in the Kattegat (Modin, 1994). The reason for this reduction may partly be eutrophication induced growth of filamentous algae in the shallow nursery areas in the Kattegat (Bagge \& Nielsen, 1988).

\section{FUTURE PERSPECTIVES}

The marine ecosystem in the southern Kattegat and the coastal areas of the Skagerrak is in disorder due to the effects of eutrophication. Affected areas have been identified by the Oslo and Paris Commission (1992; Fig. 1), and the member states have decided to reduce the input of nutrients by $50 \%$ by the year 1995 in comparison with input data ten years earlier. This goal has not been achieved by any country concerning nitrogen, but measures are in progress. At present, however, no tendency can be observed that the large-scale environmental effects are diminishing and that the ecosystem is returning towards a healthier state. In the heavily affected areas of the southeastern Kattegat a detailed temporal analysis of the Swedish riverine nitrogen input shows an increase from 1972 to 1992 . Over the last decade, the nitrogen input from farm-land has been rather stable, whereas it has increased from forest-land (Fleischer et al., 1994). Detailed measures have been implemented in the farm-land operations, but so far without results to reduce the nitrogen discharges. Over the last decades, the atmospheric deposition of nitrogen to the forest has increased and at present the soil seems to approach a stage where it may reach nitrogen saturation (Jacks et al., 1994). As a consequence, saturated soils seem to be an additional source of large nitrogen input that contributes to the marine eutrophication in that area.

Before the mid-1970s there was no awareness of eutrophication symptoms in the Skagerrak-Kattegat. Thus, this ecosystem has experienced significant environmental changes over a short period, and in the last 10 to 15 years the environmental impact has worsened. It has been suggested that eutrophication may be a self-accelerating process (e.g. Duarte, 1995). Input of nitrogen will lead to increased algal biomass and a higher sedimentation of organic material which may reduce the oxygen concentration in stratified areas. This may reduce the benthic fauna and as a consequence the aerobic/anaerobic sites in the sediment, which results of both field studies and experiments suggest are essential for the nitrification/denitrification transformations (Baden et al., 1990; Kristensen et al., 1991). The effects of hypoxia have not only been spreading in the Skagerrak-Kattegat, but occur with increasing frequency in eutrophicated, stratified coastal areas in many places all over the world, with large-scale negative effects on the benthic system and demersal fisheries (Diaz \& Rosenberg, 1995).

Elevated concentrations of nutrients have been recorded for the Kattegat and the eastern Skagerrak (Andersson \& Rydberg, 1988; Andersson, 1996; Rydberg et al., 1990). Part of these changes may be due to inflow of continental river water from the southern North Sea. Although the frequency of large inputs of this water may not be high, the amount of nutrients may at times be significant. This was manifested in recent floods in southern Germany and the Netherlands (Rydberg et al., 1996). Other sources of nutrient input are the atmosphere, rivers and municipal sewers (Table 1).

The recent findings of both widespread toxicity in the Skagerrak-Kattegat sediments and indications of physiological responses in fish and caged mussels in the Skagerrak indicate that pollutants contribute to the stress in this marine ecosystem. The extent of this contribution is not known. Information on pollutant effects is scarce in open sea areas of the Skagerrak-Kattegat, and it is not known if the contamination by pollutants over the last decades has improved or worsened. Although significant concentrations of contaminants are found in the Skagerrak-Kattegat area there should be no immediate danger to humans who consume fish or invertebrates from this area. As the deeper parts of the Skagerrak and northern Kattegat are the main accumulation areas for suspended particles from the southern North Sea (Eisma \& Kalf, 1987; Van Weering et al., 1993), a significant proportion of the contaminants found in these sediments is likely to originate from the North Sea (Rodhe \& Holt, 1996). Additional sources may be the atmosphere, Glomma and Göta Rivers, the Baltic, and local industries. The coastal zone seems, however, to trap a considerable amount of these pollutants. Finally, the apparent large-scale environmental distribution and transport of contaminants should lead to intensified efforts to reduce the flow of wastes into the sea.

\section{CONCLUSIONS}

- Input of nitrogen from the southern North Sea to the 
Skagerrak varies between years but will contribute to the eutrophication of the Skagerrak-Kattegat.

- During the last 20 years, significant increases of both nitrogen and phosphorus have been recorded in the Kattegat and the eastern Skagerrak.

- Experimental studies suggest that nitrogen is the limiting nutrient for primary production during most seasons and in most areas of the Skagerrak-Kattegat.

- Fast growing filamentous green algae have increased in coastal areas in the Skagerrak-Kattegat and changed nursery and feeding grounds for fish.

- Bottom water oxygen concentrations have declined in many areas with strong negative effects on the benthic system.

- Substantial amounts of heavy metals and organic pollutants are discharged from urbanized areas into the Skagerrak-Kattegat, but significant amounts seem to be trapped in the fine-grained, organogenic coastal sediments.

- Large quantities of particles from the .North Sea accumulate in the deeper parts of the Skagerrak-Kattegat; these particles are likely to contribute to the toxicity of these sediments as contaminants are mainly particle-bound.

- Substantial amounts of organic toxic substances are deposited in the Skagerrak-Kattegat via the atmosphere.

- Sediments from several areas of the Skagerrak-Kattegat are toxic to invertebrates and cause physiological responses in fish.

- In summary, this multi-disciplinary research project has shown large-scale environmental changes and effects on the ecosystem in the Skagerrak-Kattegat.

Acknowledgement.-We thank all participants in the research project 'Large-scale environmental effects and ecological processes in the Skagerrak-Kattegat', and acknowledge the financial support from the Swedish Environment Protection Agency. Comments to the manuscript were kindly received from Jonas Gunnarsson, Alf Josefson and Jan Magnusson.

\section{REFERENCES}

Ahnoff, M. \& B. Josefsson, 1975. Polychlorinated biphenyls (PCB) in Göta River water.-Ambio 4: 172-174.

Andersson, L., 1996. Trends in nutrient and oxygen concentrations in the Skagerrak-Kattegat.-J. Sea Res. 35: 63-71.

Andersson, L. \& L. Rydberg, 1988. Trends in nutrient and oxygen conditions within the Kattegat: Effects of local nutrient supply.-Estuar. coast. Shelf Sci. 26: 559-579.

Aure, J. \& E. Dahl, 1994. Oxygen, nutrients, carbon and water exchange in the Skagerrak basin.-Cont. Shelf Res. 14: 965-977.

Aure, J. \& D. Danielssen, 1995. Terskelbasseng på Sørlandskusten. Organisk belastning og vannutskiftning.-Fisken og Havet, Bergen 1/93: 1-16.

Baden, S.P., L.O. Loo, L. Pihl \& R. Rosenberg, 1990. Effects of eutrophication on benthic communities including fish -Swedish west coast._Ambio 19: 113-122.

Bagge, O. \& E. Nielsen, 1988. The change in abundance and growth of plaice and dab in Subdivision 22, 1962-85.-ICES Bal/No 27: 1-17 (mimeogr.).

Bergsten, H., K. Nordberg \& B. Malmgren, 1996. Recent benthic foraminifera as tracers of water masses along a transect in the Skagerrak, north-eastern North Sea.-J. Sea Res. 35: 111-121.

Bjørnsen, P.K., H. Kaas, T.G. Nielsen, M. Olesen \& K. Richardson, 1993. Dynamics of a subsurface phytoplankton maximum in the Skagerrak.-Mar. Biol. Prog. Ser. 95: 279-294.

Blomkvist, G., A. Roos, S. Jensen, A. Bignert \& M. Olsson, 1992. Concentrations of SDDT and PCB in seals from Swedish and Scottish waters. - Ambio 21: 539-545.

Bokn, T. L., S. N. Murray, F. E. Moy \& J. B. Magnusson, 1992. Changes in fucoid distributions and abundance in the inner Oslofjord, Norway: 1974-80 versus 1988-90.-Acta Phytogeogr. Suec. 78: 117-124.

De Bovée, F., P.O. J. Hall, S. Hulth, G. Hulthe, A. Landén \& A. Tengberg, 1996. Quantitative distribution of metazoan meiofauna in continental margin sediments of the Skagerrak (northeastern North Sea).-J. Sea Res. 35: 189-197.

Brorström-Lundén, E., 1996. Atmospheric deposition of persistent organic compounds to the sea surface.-J. Sea Res. 35: 81-90.

Cato, I., 1977. Recent sedimentological and geochemical conditions and pollution problems in two marine areas in south-western Sweden.-Striae 6: 1-158.

, 1983. Tungmetallbelastningen i västerhavets sediment.-Medd. Havsfiskelaboratoriet Lysekil 292: 12-34 (English summary).

- 1986. Sedimentens belastning av tungmetaller och närsalter i Göteborgs skärgård 1982, samt förändringar efter 1966. University of Göteborg, Dept. of Marine Geology, Rep. 2: 1-95 (English summary).

1990. Sedimentundersökningar | Brofjorden särskilt Trommekilen 1989, samt förändringar efter 1972 och 1984.-Geol. survey of Sweden Rapp. \& Medd., Uppsala 64: 1-75 (English summary).

1992. Sedimentundersökningar längs Bohuskusten 1990 - Göteborgs och Bohus läns kustvattenkontroll. -Geol. survey of Sweden Rapp. \& Medd., Uppsala 74: 1-97 (English summary).

Cato, I., B. Kjellin \& K. Nordberg, 1992. Bottoms and sediments. In: B. Sjöberg. Sea and coast. The National Atlas of Sweden. Almqvist \& Wiksell, Stockholm: 16-25.

Dahl, E. \& D.S. Danielssen, 1992. Long-term observations of oxygen in the Skagerrak.-ICES mar. Sci. Symp. 195: 455-461.

Dahl, E. \& K. Tangen, 1993. 25 years experience with Gyrodinium aureolum in Norwegian waters. In: T.J. Smayda \& Y. Shimizu. Toxic phytoplankton blooms in the sea. Elsevier, Amsterdam: 15-21.

Dave, G. \& E. Nilsson, 1994. Sediment toxicity in the Kattegat and Skagerrak.-J. Aquatic Ecosystem Health 3: 193-206.

Diaz, R.J. \& R. Rosenberg, 1995. Marine benthic hypoxia review of ecological effects and behavioural responses of marine macrofauna.-Oceanogr. mar. Biol. ann. Rev. 33: 245-303.

Duarte, C.M., 1995. Submerged aquatic vegetation in relation to different nutrient regimes.-Ophelia 41: 87-112.

Eisma, D. \& J. Kalf, 1987. Dispersal, concentration and dep- 
osition of suspended matter in the North Sea.-J. geol. Soc. Lond. 144: 161-178.

Fleischer, S. \& P. Jonsson, 1992. Measures counteracting eutrophication of the Kattegat. In: R.A. Vollenweider, R. Marchetti \& R. Viviani. Marine coastal eutrophication. Elsevier, Amsterdam: 1159-1164.

Fleischer, S., A. Gustafson, A. Joelsson, C. Johansson \& L. Stibe, 1994. Restoration of wetlands to counteract coastal eutrophication in Sweden. In: W.J. Mitsch. Glo bal wetlands: old world and new. Elsevier, Amsterdam: 901-907.

Förlin, L., S. P. Pihl Baden, S. Eriksson, Å. Granmo, E. Lindesjöö, K. Magnusson, R. Ekelund, A. Esselin \& J. Sturve, 1996. Effects of contaminants in roundnose grenadier (Coryphaenoides rupestris) and Norway lobster (Nephrops norvegicus) and contaminant levels in mussels (Mytilus edulis) in the Skagerrak and Kattegat compared to the Faroe Islands.-J. Sea Res. 35: 209-222.

Förlin, L., D.R. Livingstone, K. Magnusson, L.D. Peters, M. Solé, A. Sjödin \& A. Granmo, 1995. Molecular investigations into pollutant impact on roundnose grenadier (C. rupestris) and transplanted common mussel $(M$. edulis) in Skagerrak, The North Sea.-Mar. Env. Res. (in press).

Granéli, E., 1987. Dinoflagellate blooms. Occurrence, causes and consequences in the marin environment. $A$ review. -Swedish Environment Protection Board, Solna. Report 3293: 1-133.

Granéli, E., K. Wallström, U. Larsson, W. Granéli \& R. Elmgren, 1990. Nutrient limitation of primary production in the Baltic Sea area_Ambio 19: 142-151.

Gray, J.S., M. Aschan, M.R. Carr, K.R. Clarke, R.H. Green, T.H. Pearson, R. Rosenberg \& R.M. Warwick, 1988. Analysis of community attributes of the benthic macrofauna of Frierfjord/ Langesundfjord and in a mesocosm experimental.-Mar. Ecol. Prog. Ser. 46: 151-165.

Haamer, J., P.-O. Andersson, O. Lindahl, S. Lange, X.P. Li \& L. Edebo, 1990. Geographic and seasonal variation of okadic content in farmed mussels, Mytilus edulis Linnaeus 1728, along the Swedish west coast.-J. Shellfish Res. 9: 103-108.

Jacks, G., A. Joelsson \& S. Fleischer, 1994. Nitrogen retention in forest wetlands.-Ambio 23: 358-362.

Josefson, A.B., 1990. Increase of benthic biomass in the Skagerrak-Kattegat during the 1970s and 1980s effects of organic enrichment.-Mar. Ecol. Prog. Ser. 66: $117-130$.

Josefson, A.B. \& J.N. Jensen, 1992a. Effects of hypoxia on soft-sediment macrobenthos in southern Kattegat. In G. Colombo, I Ferrari, V U. Ceccherelli \& R. Rossi. Marine eutrophication and population dynamics. Olsen \& Olsen, Fredensborg, Denmark: 21- 28.

1992b. Growth patterns of Amphiura filiformis support the hypothesis of organic enrichment in the Skagerrak-Kattegat area.-Mar. Biol. 112: 615-624.

Josefson, A.B. \& R. Rosenberg, 1988. Long-term soft-bottom faunal changes in three shallow fjords, west Sweden.-Neth. J. Sea Res. 22: 149-159.

Josefson, A.B. \& B. Widbom, 1988. Differential response of benthic macrofauna and meiofauna to hypoxia in the Gullmar Fjord basin.-Mar. Biol. 100: 31-40.

Jörgensen, B.B., 1980. Seasonal oxygen depletion in the bottom waters of a Danish fjord and its effect on the benthic community.-Oikos 34: 68-76.
Karlson, B., L. Edler, W. Granéli, E. Sahlsten \& M. Kuylenstierna, 1996. Subsurface chlorophyll maxima in the Skagerrak - processes and plankton community structure.-J. Sea Res. 35: 139-158.

Kiørboe, T. H. Kaas, B. Kruse, F. Møhlenberg, P. Tiselius \& G. EErtebjerg, 1990. The structure of the pelagic food web in relation to water column structure in the Skagerrak.-Mar. Ecol. Prog. Ser. 59: 19-32.

Kristensen, E., M.H. Jensen \& R.C. Aller, 1991. Direct measurement of dissolved inorganic nitrogen exchange and denitrification in individual polychaete (Nereis virens) burrows.-J. Mar. Res. 49: 355-377.

Kuijpers, A., P.E. Nielsen, B. Larsen, I. Cato, B. Kjellin, J.B. Jensen, J.O. Leth, B. Novak \& T. Nielsen, 1992. Bottom sediments around Denmark and Western Sweden.-Geol. Survey of Sweden, Ser. Ba no. 48

Kuijpers, A., B. Dennegård, Y. Albinsson \& A. Jensen, 1993. Sediment transport pathways in the Skagerrak and Kattegat as indicated by sediment Chernobyl radioactivity and heavy metal concentrations.-Mar. Geol. 111: 231-244.

Leppäkoski, E., 1968. Some effects of pollution on the benthic environment of the Gullmarsfjord.-Helgoländer wiss. Meeresunters. 17: 291-301.

Lindahl, O. \& E. Dahl, 1990. On the development of the Chrysochromulina polylepis bloom in the Skagerrak in May-June 1988. In: E. Granéli, B. Sundström, L. Edler \& D.M. Anderson. Toxic Marine Phytoplankton. Elsevier, New York: 189-194.

Lindahl, O. \& L. Hernroth, 1983. Phyto-zooplankton community in coastal waters of western Sweden-An ecosystem off balance? -Mar. Ecol. Prog. Ser. 10: 119-126.

Lindahl, A. H., G. Persson \& H. Olsson, 1993. Eutrofiering av svenska kustområden samt omgivande hav: tillstånd, utveckling, orsak och verkan.-Swedish Environment Protection Agency, Solna. Report 4151: 1-85.

Lindahl, O. \& R. Rosenberg, 1989. The Chrysochrumolina polylepis algal bloom along the Swedish west coast 1988. Swedish Environment Protection Board, Solna. Report 3602: 1-71.

Lohse, J., 1988. Distribution of organochlorine pollutants in North Sea sediments. In: S. Kempe, G. Liebezeit, V. Dethlefsen \& U. Harms. Biogeochemistry and distribution of suspended matter in the North Sea and implications to fisheries biology.-Mitt. Geol.-Paläont. Inst., Univ. Hamburg 65: 345-365.

Magnusson, J. \& T. Johnsen, 1994. Overvåkning av fororensningssituasjonen $\mathrm{i}$ indre Oslofjord 1993.-NIVA-rapport, Oslo 3066: 1-44.

Magnusson, K., R. Ekelund, G. Dave, Å. Granmo, L. Förlin, L. Wennberg, M.-O. Samuelsson, M. Berggren \& $E$. Brorström-Lundén, 1996. Contamination and correlation with toxicity of sediment samples from the Skagerrak and Kattegat.-J. Sea Res. 35: 223-234.

Mirza, F.B. \& J. Gray, 1981. The fauna of benthic sediments from the organically enriched Oslofjord, Norway.-J. exp. mar. Biol. Ecol. 54: 181-207.

Modin, J. 1994. Information från Havsfiskelaboratoriet Lysekil. Resurs 94, del 2, hösten 1993. Fiskeriverket, Lysekil, Sweden. Nr. 1: 1-32 (mimeo).

Næs, K. \& E. Oug, 1991. Sedimentenes betydning for forurensningstilstanden i Frierfjorden og tilgrensende områder.-NIVA-rapport, Oslo 2566: 1-193.

North Sea Task Force, 1993. North Sea Subregion 8 Assessment Report 1993 State Pollution Contro 
Authority, Oslo: 1-79.

Olausson, E., 1975. Man-made effect on sediments from Kattegat and Skagerrak.-Geol. Fören. Stockh. Förh. 97: 3-12.

Olsgard, F., 1993. Do toxic algal blooms affect subtidal soft-bottom communities? -Mar. Ecol. Prog. Ser. 102: 269-286.

Oslo and Paris Commissions, 1992. Nutrients in the convention area. The Chameleon Press Ltd., London: 1-83.

Pearson, T.H., A.B. Josefson \& R. Rosenberg, 1985. Petersen's benthic stations revisited. I. Is the Kattegatt becoming eutrophic?-J. exp. mar. Biol. Ecol. 92: 157-206.

Pihl, L., I. Isaksson, H. Wennhage \& P.-O. Moksnes, 1995. Recent increase of filamentous algae in shallow Swedish bays: effects on the community structure of epibenthic fauna and fish.-Neth. J. aquat. Ecol. 29: (in press).

Pihl, L., G. Magnusson, I. Isaksson \& I. Wallentinus, 1996. Distribution and growth dynamics of ephemeral macroalgae in shallow bays on the Swedish west coast.-J. Sea Res. 35: 169-180.

Pingree, R.D., P.M. Holligan, G.T. Mardell \& R.P. Harris, 1982. Vertical distribution of plankton in the Skagerrak in relation to doming of the seasonal thermocline.-Cont. Shelf Res. 1: 209-219.

Preston, M.R., 1992. The interchange of pollutants between the atmosphere and oceans.-Mar. Pollut. Bull. 24: 477-483.

Richardson, K., 1985. Plankton distribution and activity in the North Sea/Skagerrak-Kattegat frontal area in April 1984.-Mar. Ecol. Prog. Ser. 26: 233-244.

Rodhe, J., 1996. On the dynamics of the large-scale circulation of the Skagerrak.-J. Sea Res. 35: 9-21.

Rodhe, J. \& N. Holt, 1996. Observations of the transport of suspended matter into the Skagerrak along the western and northern coast of Jutland.-J. Sea Res. 35: 91-98.

Rosenberg, R., 1990. Negative oxygen trends in Swedish coastal bottom waters.-Mar. Pollut. Bull. 21: 335-339.

Rosenberg, R., J.S. Gray, A.B. Josefson \& T.H. Pearson, 1987. Petersen's benthic stations revisited. II. Is the Oslofjord and eastern Skagerrak enriched?-J. exp. mar. Biol. Ecol. 105: 219-251.

Rosenberg, R., O. Lindahl \& H. Blank, 1988. Silent spring in the sea.-Ambio 17: 289-290.

Rosenberg, R., E. Dahl, L. Edler, L. Fyrberg, E. Granéli, W. Granéli, Å. Hagström, O. Lindahl, M.O. Matos, K. Pet- tersson, E. Sahlsten, P. Tiselius, V. Turk \& J. Wikner, 1990a. Pelagic nutrient and energy transfer during spring in the open and coastal Skagerrak.-Mar. Ecol. Prog. Ser. 61: 215-231.

Rosenberg, R., R. Elmgren, S. Fleischer, P. Jonsson, G. Persson \& H. Dahlin, 1990b. Marine eutrophication case studies in Sweden.—Ambio 19: 102-108.

Rosenberg, R., I. Cato, L. Förlin, J. Rodhe, A. Thurén \& K. Grip, 1991. Large-scale environmental effects and ecological processes in Skagerrak-Kattegat. Research programme for the period 1990-1995.-Swedish Environment Protection Agency, Solna, Report 3922: 1-79 (in Swedish with English summary).

Rosenberg, R., L.-O. Loo \& P. Möller, 1992. Hypoxia, salinity and temperature as structuring factors for marine benthic communities in a eutrophic area.-Neth. J. Sea Res. 30: 121-129.

Rosenberg, R., B. Hellman \& A. Lundberg, 1996. Benthic macrofaunal community structure in the Norwegian Trench, deep Skagerrak.-J. Sea Res. 35: 181-188.

Rueness, J. \& S. Fredriksen, 1991. An assessment of possible pollution effects on the benthic algae of the outer Oslofjord, Norway.-Oebalia 17, Suppl. 1: 223-235.

Rydberg, L., L. Edler, S. Floderus \& W. Granéli, 1990. Interaction between supply of nutrients, primary production, sedimentation and oxygen consumption in SE Kattegat.-Ambio 19: 134-141.

Rydberg, L., J. Haamer \& O. Liungman, 1996. Fluxes of water and nutrients within and into the Skagerrak.-J. Sea Res. 35: 23-38.

Stevens, R.L., H. Bengtsson \& A. Lepland, 1996. Textural provinces and transport interpretations with fine-grained sediments in the Skagerrak-J. Sea Res. 35: 99-110.

Svansson, A., 1975. Physical and chemical oceanography of the Skagerrak and the Kattegat. I. Open sea conditions.-Fishery board of Sweden, Institute of Marine Research, Rep. 1: 1-88.

Van Weering, T.C.E., G.W. Berger \& J. Kalf, 1987. Recent sediment accumulation in the Skagerrak, northeastern North Sea. - Neth. J. Sea Res. 21: 177-190.

Van Weering, T.C.E., G.W. Berger \& E. Okkels, 1993. Sediment transport, resuspension and accumulation rates in the northeastern Skagerrak.-Mar. Geol. 111: 269-285.

Van Weering, T.C.E. \& G. Qvale, 1983. Recent sediments and foraminiferal distribution in the Skagerrak, northeastern North Sea.-Mar. Geol. 52: 75-99. 